\title{
Credibility of Environmental Issues in Non-Financial Mandatory Disclosure: Measurement and Determinants
}

\author{
Federica Balluchi \\ Arianna Lazzini \\ Riccardo Torelli* \\ *Università Cattolica del Sacro Cuore - Department of Economic and Social Sciences \\ Via Emilia Parmense, 84 - 29122 Piacenza (Italy) \\ riccardo.torelli2@unicatt.it
}

\section{Introduction}

In recent decades, corporate communication has undergone significant changes in terms of channels, contents, and recipients. In order to be accountable, companies are being called upon to satisfy a plurality of stakeholders who are increasingly interested in non-financial information related to company strategies concerning corporate social responsibility (CSR) (Deegan \& Gordon, 1996; Gray et al., 1995; Guthrie \& Parker, 1989). According to legitimacy and stakeholder theories, disclosure is part of the dialog between companies and their stakeholders. Companies disclose CSR initiatives and performances with the aim of managing reputational risks (Michelon, 2011) and to achieve or increase their level of legitimacy (Dowling \& Pfeffer, 1975; Lindblom, 2010): the type and scope of information can significantly influence the competitive advantage of a company and especially its credibility (Coombs, 1992; Hur et al., 2020; Seele \& Lock, 2015; Sethi, 1975) and reputation (Miras-Rodríguez et al., 2020). CSR reports have been criticized for lack of credibility (Talbot \& Barbat, 2019; Husillos et al., 2011; Gray, 2010; Dando \& Swift, 2003) because they are considered not transparent, of poor quality, and hardly comparable (Coombs \& Holladay, 2013). For these reasons, CSR reports have been blamed for increasing the credibility gap (Doane, 2000; Perrini, 2006; Dando \& Swift, 2003; MacLean \& Rebernak, 2007) and threatening companies' legitimacy instead of facilitating dialog with their stakeholders (Seele \& Gatti, 2017). Yet, although quality of information is considered a driver of corporate reputation, there is a dearth of academic research in this area (Odriozola \& Baraibar-Diez, 2017). In the extant literature, little attention has been paid to explaining how credibility legitimizes companies. As few papers have tried to empirically operationalize the concept of credibility and measure it (e.g., Lock \& Seele, 2016, 2017) there is a need for deeper research on this subject. 
Through the lens of legitimacy theory (Suchman, 1995) and starting from Habermas's communication theory (Habermas, 1984) the aims of this study were to extend and contribute to the field of research related to the quality of CSR disclosure and corporate legitimacy by focusing on firms' reporting credibility (Helfaya \& Kotb, 2016). Considering the four statements proposed by Habermas (1984) as interconnected constructs that together constitute the multidimensional concept of credibility (Lock \& Seele, 2016) we have attempted to operationalize the concept of reporting credibility and measure its level in non-financial reporting. After identifying possible subdimensions of each claim and the related measurements and indicators we evaluated, via content analysis, the overall credibility level of CSR reports with a specific focus on environmental issues. Our sample comprised 152 "entities of public interest" that, in accordance with the Italian legislative Decree n. 254/2016 published for the first time in 2018, at a mandatory level, a CSR report disclosing their environmental, social, and governance strategies. We have also tested five hypotheses in order to search for possible relationship between the level of credibility and some corporate and environmental reporting characteristics.

Since the topic of mandatory non-financial reporting is a new phenomenon in the European context and in our case in the Italian context the field of research that deals with it is still in its beginnings. Most previous studies are based on context and documents where disclosure of CSR is voluntary. Considering the new legislation that makes the disclosure of CSR mandatory in Italy, we expected to see interesting results, also because there could exist the risk that reports are drawn up just to comply with law and not to meet the information needs of stakeholders. The passage from voluntary to mandatory disclosure affects both the quantity and the effectiveness and quality of information.

Scholars have argued that the quantity of disclosure has an implication in determining its quality (Beretta and Bozzolan, 2008) and also the scope of the reports is of great importance in determining the final quality of these documents (Helfaya \& Whittington, 2019). Despite the importance of quantity an assessment on quality has to be evaluated taking into account also other variables (Beattie et al., 2002; 2004): i.e. information types, measures, themes reported, reporting guidelines used, presence of assurance and the use of visual tools (Helfaya et al., 2018). When disclosure changes from a voluntary to a mandatory framework, its role and the relevance attributed to some of its features change. The Global Reporting Initiative (GRI) recognizes among the principles of CSR disclosure are relevance, materiality, stakeholder inclusiveness, reliability/auditability, neutrality, sustainability context, accuracy, comparability, clarity, completeness, timeliness, and transparency. While the timeliness principle is of less importance in a mandatory context because it is embedded in the regulatory norms, the neutrality, accuracy, completeness, and transparency principles become prominent. Since mandatory disclosure must be drafted to satisfy and safeguard a plurality of interests, neutrality becomes an essential requirement in CSR disclosure, characterized by narrative and subjective features.

The results of this research could be useful both for scholars to deepen their knowledge on the determinants of the credibility of SER and its link with legitimacy, and for companies and professionals in understanding the importance and complexity of the processes underlying the credibility of disclosure. The proposal of a detailed model for the measurement of social and environmental reporting 
will allow not only researchers but also corporate managers and institutions to obtain a measurement of credibility and the individual underlying dimensions. Detailed results about some analysed variables (Experience, Stand-alone, ESI, SDG) could be useful also for regulators.

The paper is composed as follows: after this introduction, we analyze the scientific literature and define the theoretical framework that helped us to identify the theories underlying the research hypotheses. Then, we deepen the methodological aspects of the research and disclose the results of the empirical analysis; after discussion on the statistical evidence, the paper concludes with some final considerations.

\section{Theoretical background}

In recent decades, disclosure has significantly changed in terms of channels, contents, and recipients (Miller \& Skinner, 2015). Through disclosure, companies provide a clear and comprehensive representation of their strategies, actions, and performances to generate, develop and maintain the approval of their stakeholders (Carnevale \& Mazzuca, 2014) and, therefore, to improve their legitimacy and reputation. The latter are two key concepts for organizations (Bitektine, 2011) and disclosure can facilitate and enhance the projection of a company's socially accountable image (Gray et al., 1995; Fombrun and Gardberg, 2000; Bebbington et al., 2008).

According to Suchman (1995: 574) legitimacy can be defined as "a generalized perception or assumption that the actions of an entity are desirable, proper, or appropriate within some socially constructed system of norms, values, beliefs, and definitions." The type and scope of information can consequently influence the competitive advantage of a company, its credibility (Coombs, 1992; Seele \& Lock, 2015; Adams \& Evans, 2004; Sethi, 1975) and its reputation (Friedman \& Miles, 2001; Roberts \& Dowling, 2002; Michelon, 2011; Odriozola \& Baraibar-Diez, 2017).

The concept of corporate reputation has been extensively analyzed in the literature (Shenkar \& Yuchtman-Yaar, 1997; Deephouse, 2000; Roberts \& Dowling, 2002; Deephouse \& Carter, 2005). Reputation reflects the extent to which a company is positively perceived by its stakeholders (Roberts \& Dowling, 2002) in comparison with other organizations regarding a variety of attributes (Deephouse $\&$ Carter, 2005). Therefore, for a company to be associated with a sustainable image and thus enjoys a positive reputation, high quality reporting, assessed by stakeholders as credible, is required (Odriozola $\&$ Baraibar-Diez, 2017). In the extant literature, little attention has been paid to explaining how disclosure is related to credibility. Although credibility is widely recognized as an important characteristic of corporate disclosure (Verrecchia, 2001; Seele \& Lock, 2015; Dunbar et al., 2015) past studies have mainly focused on decision making (Hughes \& Sankar, 1997; Verrecchia, 2001), or assurance problems (Simnett et al., 2009; Fonseca, 2010; De Beelde \& Tuybens, 2015; Al-Shaer \& Zaman, 2018). Few studies have sought to empirically operationalize the concept of credibility and measure it (e.g., Lock \& Seele, 2016, 2017). According to Jackob (2008) credibility is the consequence of an attribution process in which the recipient of a message (stakeholder) makes a personal judgment about its source and forms an opinion about it and assesses whether it is credible or not. Credibility is 
consequently strictly related to quality (and, therefore, reputation): the higher the quality of the communication, the more credible it is for the stakeholder. Nevertheless, information quality, considered a driver of corporate reputation, has been only partially studied in academic research (Michelon et al., 2015; Odriozola \& Baraibar-Diez, 2017).

A useful perspective in analyzing companies' communication process, and more specifically disclosure practices, is Habermas' theory (Habermas, 1984, 1987). Habermas differentiated the lifeworld into three structured components: culture, society, and personality. He associated these components with three "worlds," respectively: objective, social, and subjective. For each "world" he identifies a basic attitude that can be adopted (objectivating, norm-conformative, and expressive) which he relates to a corresponding rationality: cognitive-instrumental, moral-practical, and aesthetic-practical. Finally, he identifies three validity claims for each: truth, rightness, and truthfulness thematized respectively in three uses of language (constative, interactive, and expressive). Habermas assigns to each of the three components of the lifeworld a validity claim, each of which is conceived of as having a unique "inner logic" that expresses itself in a specific type of rationalization (Fleming, 1997). According to Habermas' model, the claim of validity of truth is deposited in the cultural space of science and is institutionalized in the "scientific enterprise," while the claim of validity of rightness is linked to law and morality and to the institutions of the liberal-democratic state. For the claim of the validity of truthfulness, Habermas refers to an "artistic enterprise" (Fleming, 1997 p. 156). Habermas connects the three components of the lifeworld to as many attributes of communication respectively, entitled: strategic, social, and dramaturgical. The strategic communication action is positioned to succeed in influencing the actions of others while communicative action is oriented toward reaching understanding (Habermas 1984, p. 277). Dramaturgical action is finally oriented toward self-actualization. In every communicative action a central role is played by the linguistic dimension that creates the premise for an interaction between the subjects involved in a conversation, allowing them to establish an interpersonal relationship. Communicative action is critical for studying the contributions of the elements of the lifeworld in every action system including both the state and economy dimensions. The boundaries of CSR communication are so broad that they include environmental, social, and economic aspects. As a result, reperting encompasses all three components of the lifeworld. As a result, CSR communication incorporates all the three communication actions, considering all claims identified by Habermas.

Habermas argues that every time someone communicates, claims of validity are made which has ethical and moral implications. Habermas' main claims are:

- Understandability (Verständlichkeit): ensures that the statement is clearly understandable by the actors;

- Truthful (Wahrheit): the communicator provides a true and correct message;

- Sincere expression (Wahrhaftigkeit): the communicator is truthful and believable;

- Appropriateness (Richtigkeit): in terms of social order - the actor takes a position with respect to the normative or legitimate social order. 
When speech is separated by the immediate context of action, such as for CSR disclosure, it is subject to a double organization: internal and external. The external organization concerns the ordering of discussion in time and space, including stakeholders' identification, the channel of communication, and so on. The internal organization denotes the universal pragmatic regulation of speech act sequence according to the four claims of communication. In every communication process such claims are assumed, even if only implicitly. Any judgment concerning the lack of understandability or truth of a statement within the communication process, or on a lack of sincerity or, again, on the absence of appropriateness on the part of the speaker, can only be formulated by referring to the above claims.

Habermas considers communicative action to be a tool for mutual understanding and argues that communication is a process based on the above 'norms' accepted by all communicators to construct a common understanding. Habermas argues that in a communicative action "a speaker selects a comprehensible linguistic expression only in order to come to an understanding with a hearer about something and thereby to make himself understandable" (Habermas, 1985 p. 307). On the premise of the necessary understandability claim, the communicative intent of a speaker is threefold. First, it is necessary to perform a speech in the given normative context, so as to create with the recipients (stakeholders) an intersubjective relation which is recognized as legitimate. Second, the speaker (the company) must make a true statement in order for the recipient to accept and share the message. Finally, the sender must express his message truthfully so that the recipient can give credence to what has been said (Habermas, 1987). In other words, Habermas argues that every communication process is based on a set of norms implicitly accepted that require the communicators to be comprehensible, truthful, sincere, and legitimate (Habermas, 1984). In this sense, the multidimensional and complex concept of credibility can be interpreted through the lens of Habermas's theory considering the four statements proposed by the author (Habermas, 1984) as interconnected constructs that together contribute to define the concept itself (Lock \& Seele, 2016). Therefore, considering Habermas's theory in the field of CSR communication, it can be assumed that a complete, high quality communication must have three fundamental attributes: rigor, ethical correctness, and representation in terms of truthfulness.

As noted above, a necessary precondition for a credible disclosure is its quality. A high quality disclosure is based on a complete process showing significant, comparable, and material data and information. A high quality disclosure must satisfy four properties: understandability, reliability, responsiveness, and exhaustivity. Furthermore, disclosure becomes credible when it is perceived by the stakeholders as not inconsistent with reality. High quality and consequent credibility are thus key features of a company's disclosure. Certainly, disclosure is perceived as credible when it is based on a correct communication process (Habermas, 1984).

Currently, company disclosure is subject to important change; interest toward non-financial aspects is on the increase. The importance and interest toward social and environmental aspects is proven by the increase in government regulation. In the European Union, as a result of Directive 2014/95 in force since 2017, companies are required to provide non-financial information concerning the environment, social, and employee information, human rights, anti-corruption, and diversity policies of board members 
(European Union, 2014; Ioannou \& Serafeim, 2014). In Italy, on January 10, 2017, Legislative Decree No. 254 of December 30, 2016, transposes European Union Directive 2014/95. The Decree represents an important innovation in the communication of information related to the 'sustainability' that affects companies of significant size and is an important signal of encouragement towards the promotion of sustainability disclosure (Balluchi et al., 2020). The new Decree provides for the obligation to draw up an individual non-financial report for public interest entities that have had, on average, during the financial year, more than 500 employees and, at the closing date of the financial statements, exceed at least one of two maximum limits (balance sheet total: $€ 20,000,000$; total net revenues from sales and services: $€ 40,000,000)$. The non-financial report must contain information of a social, environmental, employee-related, human rights and anti-corruption nature. It is possible not to provide information on one or more aspects if the company does not put into practice policies in these areas; but the company is required to indicate in the declaration the reasons why it is not providing such information. It is also permitted to omit information on future developments and transactions under negotiation, in the event that their disclosure could affect the commercial position of the company. The Decree states also that non-financial report must be prepared on the basis of recognised national or international reporting standard and guidelines, issued by Italian or international authorities, in compliance with the obligations of non-financial reporting provided for by Legislative Decree and Directive 2014/95/EU.

Therefore, companies are increasingly called upon to satisfy a plurality of stakeholders who are ever more interested in non-financial information concerning the matter of CSR (Deegan \& Gordon, 1996; Gray et al., 1995; Guthrie \& Parker, 1989). Social and environmental reporting (SER) is one way to manage the reputational risks (Hasseldine et al., 2005; Bebbington et al., 2008; Michelon, 2011) and achieve or increase the level of legitimacy in society (Dowling \& Pfeffer, 1975; Lindblom, 2010).

The literature suggests that companies use CSR disclosure as a legitimizing strategy to influence stakeholders' perception of their sustainability image (Deegan, 2002; O'Donovan, 2002; Sethi, 1975). Hopwood (2009) states that CSR disclosures can be used by companies to facilitate the construction of a company's reputation and increase its legitimacy. In this way a systematic dialog with stakeholders has become the cornerstone of all accountability mechanisms (Larsson \& Ljungdahl, 2001; Zadek \& Raynard, 2002; Unerman \& Bennett, 2004). It is largely recognized that companies report on CSR to foster their reputation, respond to the information needs of stakeholders, and demonstrate their ethical commitment (Dando \& Swift, 2003). However, due to the predominantly narrative nature of CSR information, several studies have indicated that there is strong doubt regarding whether CSR disclosure can provide a true and fair view of a company's CSR performance (Bouten, et al. 2011; Hodge et al., 2009; Bachmann \& Ingenhoff 2016).

CSR reports have been criticized for lack of credibility (Michelon et al., 2015; Husillos et al., 2011; Gray, 2010; Dando \& Swift, 2003) because they are considered not transparent, of poor quality and hardly comparable (Coombs \& Holladay, 2013). For these reasons, CSR reports have been accused of increasing the credibility gap (Doane, 2000; Perrini, 2006; Dando \& Swift, 2003; MacLean \& Rebernak, 
2007) and threatening companies' legitimacy and reputation instead of facilitating dialog with their stakeholders (Seele \& Gatti, 2017).

\section{Research methodology}

\section{Theoretical model}

Based on the theoretical background proposed in the previous paragraph, through the lens of legitimacy theory (Suchman, 1995) and using Habermas's theory of communicative action as a start point (Habermas, 1984), we have attempted to contribute to the field of research related to SER quality and corporate legitimacy by focusing on firms' reporting credibility. In fact, credible disclosure is, in turn, a necessary condition for the improvement of a company's legitimacy (Suchman, 1995). Considering Habermas' necessary claims for a communication process (understandability, truth, sincere expression, appropriateness) as interconnected constructs that together constitute the multidimensional concept of credibility (Lock \& Seele, 2016), we aimed to operationalize the concept of reporting credibility and to measure its level in non-financial reports published for the first time by Italian companies in accordance with the new law (legislative Decree No 254/2016). As already noted in the introduction, the originality of this paper lies in the fact that previous contributions on this subject have analyzed CSR reports which have been voluntarily published by companies.

The communication process put in place by companies in the drafting of a report takes the form of a message that goes from a speaker (company) to a recipient (stakeholder) without the latter being able to respond. In order to assess the credibility of this message, the recipient must be able to receive it as easily as possible (Hammond \& Miles, 2004). With specific reference to a report, therefore, this means that it must at least be available online in a pdf or multimedia version. The ease with which a report can be found and consulted, can, in our opinion, be a first proxy to measure the comprehensibility of a document. Once the message is received, it is important that it is legible (Barnett \& Leoffler, 1979; Courtis, 1986; Jones \& Shoemaker, 1994) and contains all the information necessary for its comprehension. For a social and environmental report, this means that it must first contain a section in which the company explains the principles and criteria based on which it has prepared the report. It is also essential that the report sets out how any performance indicators have been calculated as well as any additional information that helps the reader understand the message the company is sending. In conclusion, understandability (intelligibility, clarity, or degree of comprehensiveness of the message) is a necessary (but not sufficient) condition for a report to meet the information needs of stakeholders. In other words, a report must primarily be understandable in order to be credible (Zinkin, 1998; Lock \& Seele, 2016). According to Habermas' theory understandability is not only guaranteed by the ability of the receiver of the information to understand and "read" it correctly, but it is equally guaranteed by the ability and willingness of the sender to make the information available, "audible" and understandable. A report, therefore, should contain truthful and honest statements (the truthful and sincere expression of Habermas, 1984); these features may be reinforced by the fact that a disclosure document has been prepared in application of a standard or guideline (e.g., GRI standard). In addition, both the achievement 
of certifications (e.g., environmental certifications) and the identification of a corporate CSR manager can be important elements for the reliability of the information contained in a report. Another element that we identified as proxies of the reliability of the information contained in a report is the presence of time comparisons of key performance indicators (KPI) values that do not describe only positive trends. We further believe that in order for the message to be credible, it must be suitable (the appropriateness of Habermas' communication theory) for the recipient of the information. For a report to be appropriate to a recipient, he must be interested in the information contained within. In this sense, the more the company is able to map and to engage its stakeholders, the more it can provide information which is considered adequate and useful. At the same time, systematic stakeholder engagement enables companies to identify the issues (social and environmental) that are significant (or material) to them, and to which stakeholders expect responses in terms of strategic policies and communication.

The last dimension, that in our opinion makes up the concept of the credibility of a report, is exhaustivity (completeness). This is a dimension that integrates those foreseen by Habermas's theory and represents an important element for evaluating the credibility of a report. In fact, on a specific issue (e.g., environmental), the more "material" information (reliable and appropriate) provided by the company, the more the information needs of the stakeholder will be met.

In conclusion, a company acquires or improves its legitimacy with respect to its stakeholders when the process of communication with them is more credible. In order to assess the credibility of the information provided, it is first of all necessary that it is understandable and accessible. However, its comprehensibility by stakeholders is not sufficient to ensure their credibility; it is important that the information is reliable, adequate (suitable) and exhaustive to meet the information needs of those who receive the message. In light of this approach, Figure 1 presents the theoretical model underlying our research.

\section{---- Here Figure 1 ----}

The problem, now, is how to measure credibility and, therefore, place value on its dimensions.

\section{Research aims}

Our research is focused on the information that the company provides on environmental issues, focusing in particular on the sections, paragraphs, or information devoted to this matter in the CSR report. This choice was dictated by the fact that the environmental aspect of sustainability, and therefore of corporate responsibility, is now the focus of attention of people, market, institutions, and society in general. As the Intergovernmental Panel on Climate Change (IPCC, 2019) pointed out, we are facing environmental events and changes on a global scale, some of which are often extremely violent. In this scenario, companies, in their role as productive resources of the economy (Bansal, 2002), have a significant impact on environmental issues and for this reason, especially today, they face complex challenges of responsibility and correct communication. In view of this, our first aim was to measure, with a specific 
focus on the environment, the level of credibility of the first mandatory non-financial reporting of Italian companies.

Starting from the research model proposed in the previous paragraph and from the literature on the subject (e.g., Hammond \& Miles, 2004; Michelon et al., 2015; Lock \& Seele, 2016 and 2017; Pistoni et al., 2018), in Table 1, we proposed a series of variables to measure the four dimensions of credibility of environmental disclosure (understandability, reliability, suitability, exhaustivity):

---- Here Table 1 ----

The methodology we used to collect this information was manual quantity content analysis (Riffe et al., 1998; Campbell, 2003; Krippendorff, 2013). To measure the readability of the report, we used the Gulpease Index which is an index of the readability of a text calibrated on the Italian language. It is an index created in 1982 starting from the Italian language and recognized as the best readability index for this language (Lucisano \& Piemontese, 1988). Compared to others it has the advantage of using the length of words measuring the number of letters instead of syllables, which simplifies the automatic calculation. To apply this indicator, each report was converted from a pdf to a word file. Subsequently, we carefully analyzed the information provided in the methodological note (where present) and the information concerning the company stakeholders (mapping and engagement). We then proceeded to measure the various dimensions (through its variables) of credibility with respect to the disclosure specifically provided on environmental issues.

Our subsequent goal was to verify the following hypotheses by taking advantage of the accurate analysis of the level of credibility offered by this work to be able to give further insights and results on these debated variables ${ }^{1}$.

\section{Environmental sensitive industry $\left(H p_{1}\right)$}

As already analyzed by several scholars (Jenkins \& Yakovleva, 2006; Branco \& Rodrigues, 2008; (Fifka, 2013; Hahn \& Kühnen 2013; Lock \& Seele, 2016; Raufflet et al., 2014), we assumed that companies that belong to an environmentally sensitive sector (e.g., chemicals, construction materials, energy, extraction, forestry) were induced to provide credible information to improve their reputation and legitimacy. The classification of industry used in this study is the U.S. Standard Industrial Classification (SIC).

$\mathrm{HP}_{1}$ : There is a positive relationship between credibility and environmentally sensitive industry (ESI).

Pursuit of environmental SDGs $\left(\mathrm{Hp}_{2}\right)$

\footnotetext{
${ }^{1}$ The five tested variables have been carefully selected from the most recent studies on the quality of environmental reporting mentioned for each hypothesis presented in this paragraph. These are the company and reporting characteristics currently most considered and most debated, even with discordant results.
} 
While there are studies that investigate the relationship between a company's commitment to social and environmental issues and the quality of the information provided in its annual report (e.g., Ben-Amar \& Belgacem, 2018), there are none which analyze the relationship between the credibility of a CSR report and the company's commitment to sustainability. We argue that the more a company commits itself to social and environmental issues by obtaining certification from independent bodies, or by signing commitments recognized by international agendas (e.g., 2030 Agenda for Sustainable Development by United Nations), the more reliable and credible is the information provided to its stakeholders. The issue of the communication credibility of companies actually committed to sustainability is considered of great importance in relation to UN SDGs (Gold Standard and WWF Switzerland, 2018). Since this is a new reference framework for sustainability, it can give companies that want to adopt it in their strategy the opportunity to improve their image externally and to obtain some competitive and reputational advantages (GRI and UN Global Compact, 2018). With specific reference to the environmental issue and with the objective of verifying hypothesis 2 , we therefore verified the presence or absence in the reports of a commitment to at least one of the Sustainable Development Goals (SDGs) listed below ${ }^{2}$ :

N. 6: Ensure availability and sustainable management of water and sanitation for all

N. 7: Ensure access to affordable, reliable, sustainable, and modern energy for all

N. 12: Ensure sustainable consumption and production patterns

N. 13: Take urgent action to combat climate change and its impacts

N. 14: Conserve and sustainably use the oceans, seas, and marine resources for sustainable development N. 15: Protect, restore, and promote sustainable use of terrestrial ecosystems, sustainably manage forests, combat desertification, and halt and reverse land degradation and halt biodiversity loss.

It would be reasonable to assume that a company that declares its commitment to the SDGs has an interest in communicating its environmental strategies and results in a credible manner. (This hypothesis has not so far been analyzed in the literature.)

$\mathrm{HP}_{2}$ : Tthere is a positive relationship between credibility and pursuit of environmental SDGs.

Environmental scandals and external pressures $\left(\mathrm{Hp}_{3}\right)$

We searched on the World Wide Web for any environmental scandals or external pressures by environmental associations in which the company had been involved in the past. The previous literature highlighted how scandals and environmental pressures can significantly influence environmental communication (Alrazi et al., 2016; Clarkson et al., 2008). Our goal is to understand whether the credibility of this corporate communication is also affected by past scandals or external pressures.

$\mathrm{HP}_{3}$ : There is a relationship between credibility and the presence of environmental scandals and external pressures.

Experience in social and environmental reporting $\left(\mathrm{Hp}_{4}\right)$

\footnotetext{
${ }^{2}$ https://sustainabledevelopment.un.org/
} 
As has already been pointed out in other studies (e.g., Albertini, 2014; Lock \& Seele, 2016; Venturelli et al., 2019), a variable that can influence the quality of CSR reports and, therefore, the credibility of the information contained therein, is represented by the experience that the company has acquired over time on this practice. We assumed that the CSR reports published in financial year 2017 by companies that had already voluntarily informed their stakeholders about their social and environmental policies would be more credible than those published by companies that have prepared them in compliance with the law. To verify this hypothesis, we consider "past experience" on SER in any reports voluntarily published by a company before year 2018 .

$\mathrm{HP}_{4}$ : There is a positive relationship between credibility and past experience in social and environmental reporting.

\section{Stand-alone non-financial report $\left(\mathrm{Hp}_{5}\right)$}

Several scholars (e.g., Kolk, 2004; Adams and Simnett, 2011; Frias-Aceituno et al., 2013; Dhaliwal et al., 2014; Michelon et al., 2015; Lock \& Seele, 2016) have investigated the relationship between the quality of a CSR report and its format (combined report or stand-alone report). The use of a stand-alone report does not only imply a greater amount of information provided on the topics covered by the disclosure, and the quantity of information cannot be considered the only element to assess the credibility of the document. We believe that the use of a specific document dedicated to socioenvironmental issues can also influence the quality of the information provided in terms of comprehensibility, reliability, adequacy, and completeness with respect to the information needs of stakeholders (Hackston \& Milne, 1996; Unerman, 2000; Garegnani et al., 2015).

$\mathrm{HP}_{5}$ : There is a positive relationship between credibility and a stand-alone social and environmental report.

\section{Sample}

Our sample consisted of companies that have published a non-financial report for the 2017 financial year, in accordance with legislative Decree No 254/2016 that requires "public interest entities" to integrate statutory financial statements with a disclosure of environmental, social, and governance strategies. As we have already observed, we analyzed Italian companies because in Italy, since the financial year 2017, SER has moved from a voluntary to a mandatory perspective; this is why we found it interesting to investigate the credibility of a report that has been drawn up in compliance with a legal provision. The risk is that reports drawn up just to comply with law might not meet the information needs of stakeholders.

The total number of "public interest entities" who have published a non-financial report for the 2017 financial year in compliance with the law was $208 .{ }^{3}$ We excluded 53 companies operating in the finance

\footnotetext{
${ }^{3}$ Official list of August 31, 2018 and updated on December 31, 2018, available on CONSOB - National Commission for Companies and Stock Exchanges website.
} 
and insurance industry which is characterized by a specific system of information and regulations (La Porta et al., 2002). For three companies, non-financial reports were not available, thus the final sample comprised 152 companies.

The table below show the percentage distribution of companies in relation to industry (Table 2):

\section{---- Here Table 2 ----}

Of the total number of companies studied, around $85 \%$ are listed on the stock exchange with $16 \%$ in the FTSE MIB ${ }^{4}$. For $57 \%$ of the cases, the 2017 financial year report was their first experience in SER; almost all companies (around 99\%) referred to the GRI guidelines (21\% G4 and 78\% GRI Standard) and $76 \%$ declared they had environmental certification.

With reference to UN SDGs, $37 \%$ of the sample refers in its non-financial document to at least one environmental goal (Table 3).

\section{---- Here Table 3 ----}

In the following paragraphs, we will explain and discuss the results of the statistical analysis.

\section{Statistical analysis: results and discussion}

The average values of the different variables that operationally measure the four dimensions of credibility (rated from 0 to 10) are reported in Table 4. It is interesting to note that the minimum value reported (2.4), i.e., the variable with the most negative impact on the overall value of credibility of the Italian 2017 reports, is that which refers to the presence in the company of a CSR manager (or Sustainability Manager, or similar). This is an extremely concise but quite significant figure of the weight given by the companies surveyed to the macro-theme of social and environmental responsibility and the reporting of activities related to it. The maximum value (9.8), i.e., the variable with the most positive impact on the overall credibility value, refers to the internal nature of the author(s) of the nonfinancial report analyzed. In this case, for different reasons, companies have decided in almost all cases to rely on an internal author, who should have a much higher vision and knowledge of the society to which they belong than a possible external author recruited for the purpose. It is also noted that the two extreme values both belong to the subdimension of Reliability.

\section{---- Here Table 4 ----}

The same average value, rated from 0 to 10 , referring to the four dimensions of credibility and credibility itself is shown in Table 5. In this case the lowest average value is represented by Exhaustivity (5.1).

\footnotetext{
${ }^{4}$ Financial Times Stock Exchange Milano Index (Borsa) is the leading benchmark index of the Italian stock market.
} 
With a value so close to the median (5) it can be stated that on average the Italian companies surveyed do not produce and publish exhaustive reports on environmental issues. In particular, in analyzing the average values of the variables related to Exhaustivity (Table 4), shows that despite the presence of environmental issues in the materiality matrices being analysed (average value of 8.9), the percentage of KPIs related to the environment used with respect to those proposed by the GRI standards is rather low (average value of 3.3). Also the weight of the environment theme in the report, measured by the ratio of the number of words to the total number of words in the report, is rather low with an average value of 2.6. The maximum average value in this analysis of the four dimensions is Understandability with an average value of 7.9. Analysis of operative variables (Table 4) highlighted how the presence of the methodological note is widely used in favor of a greater understanding, but also how explanation of key performance indicators has an high value (8.9). In terms of the minimum and maximum values reached by each individual company analyzed, Table 5 shows that only in the case of Suitability were the limit values of 0 and 10 reached. These extreme scores are due to the fact that there is great variability in the companies analyzed from the point of view of stakeholder engagement and the level of application of the principle of materiality. As far as the average value of credibility is concerned, this stands at 6.2 with a minimum peak of 2.59 and a maximum peak of 8.52 .

\section{---- Here Table 5 ----}

As previously analyzed (see paragraph "Theoretical background") the concept of communication credibility, starting from Habermas's theory, refers to the presence of four conditions (i.e. validity claims): it is fundamental to verify if and to what degree these subdimensions are related to each other. Being an integral and interconnected part of a single theoretical construct, credibility, they must be connected and linked to each other, otherwise the basic logical-theoretical construct would not hold up. In this case, as can be seen from Table 6, the four subdimensions (understandability, reliability, suitability and exhaustivity) are related to each other with different degrees of intensity and are able therefore, together, to give life to the credibility construct measure. In particular reliability, suitability and exhaustivity are all strongly related to each other. As a further verification and confirmation, Cronbach's Alpha value was calculated: this was equal to 0.78 , confirming the statistical reliability.

\section{---- Here Table 6 ----}

Proceeding with the statistical analysis, a statistical model was created and subjected to multiple linear regression after carrying out the necessary tests. As control variables we inserted profitability (measured by ROA - Return on Assets), company size (measured by Total Assets), assurance of non-financial report (dichotomous variable), visibility (dichotomous variable that explains the presence or absence of 
the company in the most significant stock index of Borsa Italiana, the FTSE MIB), and leverage (ratio between total debt and total assets) $)^{5}$.

Credibility $=\alpha+\beta 1$ ESI $+\beta 2$ SDG $+\beta 3$ Scandal\&Pressure $+\beta 4$ Experience $+\beta 5$ Stand-alone $+\beta 6$ Profitability $+\beta 7$ Size $+\beta 8$ Assurance $+\beta 9$ Visibility $+\beta 10$ Leverage $+\varepsilon$

All the independent variables present in the model have been introduced and justified with reference to the research hypotheses in the paragraph Research methodology, Aims and hypothesis. The descriptive statistics of all variables in the model are shown in Table 7. It is interesting to note that two characteristics widely present in the sample are the publishing of a stand-alone report and the assurance of the report itself. On the contrary there is a low presence of companies operating in ESI sectors, a low percentage of companies that have suffered scandals or pressure from external parties and a low number of companies that are present in the most significant stock index of Borsa Italiana, the FTSE MIB.

\section{---- Here Table 7 ----}

\section{---- Here Table 8 ----}

The multiple linear regression model built on the dependent credibility variable and with the industry inserted as fixed effect was significant at the $1 \%$ level with an $\mathrm{R}^{2}$ of 0.3 .

The test shows a significant relationship (at 5\%) with the independent variable Experience and a positive $\beta(0.47)$ which indicates a positive relationship between the dependent variable and this independent variable. This result confirms hypothesis 4 (a significant relationship between the credibility of a social environmental report and a company's past experience in producing voluntary non-financial reports). This is an important confirmation of an issue which was recently the subject of several studies (Albertini, 2014; Lock \& Seele, 2016; Venturelli et al., 2019). The result shows how having already faced the challenge at organizational, communication, and responsibility levels in the years prior to non-financial reporting becoming mandatory gave an advantage and a positive boost in terms of understandability, reliability, suitability, exhaustivity and, more generally, the credibility of the information produced and published. The reports published in 2018, referring to the year 2017, are also interesting because it is the only year in which companies with past experience can be compared with companies that have published for the first time a socio-environmental report required by the new national legislation (legislative Decree No 254/2016). The past experience recalls several possible factors that may have influenced better credibility of the communication: adaptation over time to the requests of stakeholders,

\footnotetext{
${ }^{5}$ For control variables usually needed in CSR studies see Cahan et al., 2015 and 2016, and Martínez-Ferrero \& García-Sánchez, 2017.
} 
change following external stimulus/corrections, verification and correction of its work, step by step evolution toward increasingly advanced, pervasive, and complete information-gathering and reporting processes. As in all communications, as well as corporate communications, there is a greater understanding and mutual refinement with the passage of time.

The regression also showed a positive $(\beta=0.56)$ and significant relationship (at $1 \%)$ with the independent stand-alone variable. This result confirms hypothesis 5 of a relationship between credibility and the presence of a socio-environmental report published in a document specifically dedicated to this information. This is a relevant topic in the reference literature (Kolk, 2004; Adams \& Simnett, 2011; Jensen \& Berg, 2012; Frias-Aceituno et al., 2013; Dhaliwal et al., 2014; Michelon et al., 2015; Lock \& Seele, 2016) and has important practical implications. The statistical result highlights how the publication of non-financial information in a separate, dedicated document ensures greater credibility of the information disclosed. The use of a stand-alone document guarantees not only more space and therefore more information, but also more attention to and more in-depth analysis of the topics covered. With reference to legislative Decree No 254/2016, it is interesting to note that this does not oblige companies to produce separate non-financial reports but allows the possibility of integrating this information into existing financial statements.

\section{---- Here Table 9 ----}

As a further elaboration and continuation of the statistical analysis, a comparison of the average credibility value between specific clusters of the sample under investigation was conducted. The averages obtained were subjected to $t$-tests to verify whether or not the difference was significant. Table 9 shows the variables that have shown a significant difference.

Related to Hypotheses 4 and 5, both the Experience variable and the Stand-alone variable are confirmed as related to credibility (at a level of $1 \%$ ).

This analysis also confirms hypothesis 1 on the existence of a relationship between the credibility of the SER and whether or not a company belongs to a sector sensible to environmental issues. The average credibility of companies belonging to an ESI is significantly higher than the rest of the sample at a level of $10 \%$. Further deepening of the analysis emphasized that in particular there were significant differences for Industry 5 (Transportation, Communications, Electric, Gas, and Sanitary Services) and Industry 9 (Services). The companies belonging to the specific sectors contained in Industry 5 had a significantly higher credibility in their communications than the other companies (at a level of $1 \%$ ). Meanwhile Industry 9 companies had significantly less credibility in their communications than the remaining sectors (at a level of 5\%). These results highlight how being active in a sector sensitive to environmental issues (as part of the activities included in Industry 5) leads to greater attention by companies in non-financial communication to the outside world. It is likely that the greater attention paid by stakeholders, society, institutions, market, and financiers to these companies (given their possible impact on the environment) leads to a greater commitment to the production and publication of 
reports and therefore credible information in accordance with the four dimensions is reported in the theoretical model.

Finally, the comparison of means tests confirms hypothesis 2 that there is a relationship between the credibility and treatment of at least one environmental UN SDG. The statistical evidence showed that companies who cite paying attention to at least one environmental SDG $(6,7,12,13,14$ and 15) have a higher credibility in their reporting (at a level of significance of 1\%). This positive relationship between credibility and the treatment of environmental SDGs leads us not only to reflect on the current importance for companies to meet the challenges and objectives set by the UN but also the importance that is evidently given to this issue from outside the company. It would be fair to say that a company committed to the treatment and consideration of the sustainable development objectives proposed by the UN pays great or greater attention, both in practice and in reporting, to its environmental impact and responsibilities. It is therefore a sign of a greater commitment, a greater depth of reflection and, therefore, a more careful and more credible reporting.

Hypothesis 3, regarding a relationship between the credibility of the SER and the presence of scandals or particular pressures (environmental associations), was not confirmed.

It should be noted that the assurance variable (control variable) was significantly and positively linked with the dependent variable $(\mathrm{p}<0.05 ; \beta=0.59)$, proving the important link between the credibility of a report and its assurance by an external body.

All the necessary tests for a correct statistical analysis were carried out: normal distribution (JarqueBera test), homoscedasticity (White test) and multicollinearity (Variance inflation factor - VIF value).

\section{Conclusions}

Starting from the theoretical pillars of the theory of communicative action (Habermas, 1984) and adapting it to a corporate context and more specifically to the context of environmental reporting by Italian companies after the introduction of legislative obligation, the credibility measurement model proposed in the paragraph "Research methodology" was initially applied and finally the possible relationships between the credibility of corporate environmental communications and some peculiar characteristics of companies, or of the communication itself were analyzed through statistical analysis (see hypotheses). The proposed credibility measurement model made it possible to understand how each subdimension of the concept of credibility had an impact on the final measurement and the credibility of the environmental information provided by large Italian companies obliged by legislative Decree No. $254 / 2016$ to provide non-financial information. The results confirm a good level of credibility of Italian reporting in 2017 (with an average of 6.2 on a scale from 0 to 10) and in particular a high level of understandability (average value of 7.9), and a low level of exhaustivity (average value of 5.1). Subsequent analyses first confirmed the assumptions regarding a relationship between the credibility of the Italian SER and (1) the presence of past experience in voluntary non-financial reporting, and (2) the publication of social and environmental information in a dedicated stand-alone document. Secondly it was also highlighted that both belonging to an ESI sector and treatment in the report of at least one of 
the sustainable development objectives related to the environment had a significant and positive relationship with the credibility of environmental information,

These results offer implications and scientific contributions primarily for the proposal of a detailed model for the measurement of social and environmental reporting applicable to any type of document, in any geographical contest, and any time frame. Although the credibility of companies' social and environmental communication is at the centre of attention of corporate reporting scholars (Dando \& Swift, 2003; Doane, 2000; Gray, 2010; Husillos et al., 2011; MacLean \& Rebernak, 2007; Perrini, 2006; Talbot \& Barbat, 2019), few studies have deepened this concept (Lock \& Seele, 2016, 2017) and there is a lack of studies analysing in detail the determinants and conditions of development of the credibility of a corporate report. This measurement tool will allow not only researchers but also corporate managers and institutions to obtain a measurement of credibility and the individual underlying dimensions. In this respect this study has an immediate relevance for the Italian context where the most recent studies have shown a strong growth trend in the publication of non-financial reports, especially after the entry into force of the legislative decree (Balluchi et al., 2020), without however providing details on the quality and credibility of these communicative tools. Second, the indication of some variables significantly related to the measurement of credibility (Experience, Stand-alone, ESI, SDG) offers insights into both the current situation and future trends in corporate reporting, also potentially useful for regulators who intend to approach the issue of non-financial reporting and its quality. Further implications and contributions concern the professional and managerial sphere: the definition of an empirical model of measurement based on theoretical/scientific pillars and the results of its first application to the Italian post-regulation contest of non-financial reporting offers opportunities for real implementation in companies that are immersed in the field of communication and reporting, associations that monitor the trend of national or extra-national reporting, and institutions that intend to propose new regulations or changes to the current SER.

Like all scientific work, the current study has its limits. The first concerns the time factor: the analysis was carried out over a single year, albeit of particular interest due to the transition to the new national regulations. The second concerns the spatial factor: the analysis was carried out on a single country (Italy). The third concerns the particular focus on the environment: environmental information was analyzed because of its weight and importance at the moment in the corporate, social, and human panorama. The fourth concerns the same theoretical/empirical model on credibility: although the subdimensions and operational variables emerge from a reflection that refers to scientific contributions and consolidated theories, and although in the first practical application the four subdimensions are correctly correlated and linked (see correlation of Spearman and Cronbach's Alpha) this model may not be complete and could be further developed.

Future research could first of all deal with improving, deepening, implementing the credibility measurement model, both from a theoretical and empirical point of view. Secondly there is an interesting glimmer of future contributions on the measurement through the model itself of the credibility of the 
SER in countries other than Italy, in longer periods of time, adopting international comparisons and analyzing not only the environmental component but also the social, economic and governance one.

\section{Acknowledgements}

We wish to thank participants at the $5^{\text {th }}$ French CSEAR Conference on Social and Environmental Accounting Research (Paris - June 3-4, 2019), in particular those who have given us suggestions, comments, and compliments. We want also to thank Peter Seele (Professor of Corporate Social Responsibility and Business Ethics at USI Lugano, Switzerland) for his inspiring presentation at 31st EBEN Annual Conference (Tilburg - June 27-29, 2018) and for his valuable tips.

\section{References}

Adams, A., \& Evans, R. (2004). Accountability, completeness, credibility and the audit expectations gap. Journal of corporate citizenship, 14, 97-115.

Adams, S., \& Simnett, R. (2011). Integrated reporting: an opportunity for Australia's not-for-profit sector. Australian Accounting Review, 21(3), 292-301.

Albertini, E. (2014). A descriptive analysis of environmental disclosure: A longitudinal study of French companies. Journal of Business Ethics, 121(2), 233-254.

Alrazi, B., Villiers, C. de, \& Staden, C. J. V. (2016). The environmental disclosures of the electricity generation industry: A global perspective. Accounting and Business Research, 46(6), 665-701. https://doi.org/10.1080/00014788.2015.1135781

Al-Shaer, H. \& Zaman, M. (2018) Credibility of sustainability reports: The contribution of audit committees. Business Strategy and the Environment, 27(7), 973-986.

Bachmann, P., \& Ingenhoff, D. (2016). Legitimacy through CSR disclosures? The advantage outweighs the disadvantages. Public Relations Review, 42(3), 386-394.

Balluchi, F., Furlotti, K., \& Torelli, R. (2020). Italy Towards Mandatory Sustainability Reporting. Voluntary Corporate Social Responsibility Disclosure of Italian Companies and Legislative Decree 254/2016 Statements. A Quantitative Analysis of the Last 10 Years. In V. Mauerhofer, D. Rupo, \& L. Tarquinio (A c. Di), Sustainability and Law: General and Specific Aspects (pagg. 257-274). Springer International Publishing. https://doi.org/10.1007/978-3-030-42630-9_14

Bansal, T. (2002). The corporate challenges of sustainable development. Academy of Management Perspectives, 16(2), 122-131.

Barnett, A., \& Leoffler, K. (1979). Readability of accounting and auditing messages. Journal of Business Communication, 16(3), 49-59. 
Beattie, V. A., Fearnley, S., \& McInnes, W. M. (2002). Through the eyes of management: A study of narrative disclosures. Institute of Chartered Accountants in England and Wales. Centre for Business Performance. London (UK).

Beattie, V. A., Fearnley, S., \& McInnes, W. M. (2004). A methodology for analysing and evaluating narratives in annual reports: a comprehensive descriptive profile and metrics for disclosure quality attributes. Accounting Forum, 28(3), 205-236. https://dx.doi.org/10.1016/j.accfor.2004.07.001

Bebbington, J., Larrinaga, C., \& Moneva, J. M. (2008). Corporate social reporting and reputation risk management. Accounting, Auditing \& Accountability Journal. Vol. 21 No. 3, pp. 337-361.

Ben-Amar, W., \& Belgacem, I. (2018). Do socially responsible firms provide more readable disclosures in annual reports? Corporate Social Responsibility and Environmental Management, 25, 10091018.

Beretta, S., \& Bozzolan, S. (2008). Quality versus Quantity: The Case of Forward-Looking Disclosure. Journal of Accounting, Auditing \& Finance, 23(3), 333-376. https://doi.org/10.1177/0148558X0802300304

Bitektine, A. (2011). Toward a theory of social judgments of organizations: The case of legitimacy, reputation, and status. Academy of management review, 36(1), 151-179.

Bouten, L., Everaert, P., Van Liedekerke, L., De Moor, L., \& Christiaens, J. (2011, September). Corporate social responsibility reporting: A comprehensive picture? In Accounting Forum (Vol. 35, No. 3, pp. 187-204). Taylor \& Francis.

Branco, M. C., \& Rodrigues, L. L. (2008). Factors influencing social responsibility disclosure by Portuguese companies. Journal of Business Ethics, 83(4), 685-701.

Cahan, S. F., Chen, C., Chen, L., \& Nguyen, N. H. (2015). Corporate social responsibility and media coverage. Journal of Banking \& Finance, 59, 409-422. https://doi.org/10.1016/j.jbankfin.2015.07.004

Cahan, S. F., De Villiers, C., Jeter, D. C., Naiker, V., \& Van Staden, C. J. (2016). Are CSR disclosures value relevant? Cross-Country Evidence. The European Accounting Review, 25(3), 579-611. https://doi.org/10.1080/09638180.2015.1064009

Campbell, D. (2003). Intra-and intersectoral effects in environmental disclosures: evidence for legitimacy theory? Business Strategy and the Environment, 12(6), 357-371.

Carnevale, C., \& Mazzuca, M. (2014). Sustainability reporting and varieties of capitalism. Sustainable Development, 22(6), 361-376.

Clarkson, P. M., Li, Y., Richardson, G. D., \& Vasvari, F. P. (2008). Revisiting the relation between environmental performance and environmental disclosure: An empirical analysis. Accounting, Organizations and Society, 33(4), 303-327. https://doi.org/10.1016/j.aos.2007.05.003

Coombs, W. T. (1992). The Failure of the Task Force on Food Assistance: A Case Study of the Role of Legitimacy in Issue Management. Journal of Public Relations Research, 4(2), 101-122. https://doi.org/10/bgg2j3 
Coombs, W. T., \& Holladay, S. J. (2013). The pseudo-panopticon: the illusion created by CSR-related transparency and the internet. Corporate Communications: An International Journal, 18(2), 212227.

Courtis, J. K. (1986). An investigation into annual report readability and corporate risk-return relationships. Accounting and Business Research, 168(64), 285-294.

Dando, N., \& Swift, T. (2003). Transparency and assurance minding the credibility gap. Journal of Business Ethics, 44(2-3), 195-200.

De Beelde, I., \& Tuybens, S. (2015). Enhancing the credibility of reporting on corporate social responsibility in Europe. Business Strategy and the Environment, 24(3), 190-126.

Deegan, C. (2002). The legitimising effect of social and environmental disclosures-a theoretical foundation. Accounting, Auditing \& Accountability Journal, 15(3), 282-311.

Deegan, C., \& Gordon, B. (1996). A Study of the Environmental Disclosure Practices of Australian Corporations. Accounting and Business Research, 26(3), 187-199. https://doi.org/10/gfv3gg

Deephouse, D.L. (2000). Media reputation as a strategic resource: An integration of mass communication and resource-based theories. Journal of management, 26(6), 1091-1112.

Deephouse, D.L., \& Carter, S. M. (2005). An examination of differences between organizational legitimacy and organizational reputation. Journal of management Studies, 42(2), 329-360.

Dhaliwal, D. S., Li, O. Z., Tsang, A., \& Yang, Y. G. (2014). Corporate social responsibility disclosure and the cost of equity capital: The roles of stakeholder orientation and financial transparency. Journal of Accounting and Public Policy, 33(4), 328-355.

Doane, D. (2000). Corporate Spin: The Troubled Teenage Years of Social Reporting. London: New Economics Foundation.

Dowling, J., \& Pfeffer, J. (1975). Organizational Legitimacy: Social Values and Organizational Behavior. The Pacific Sociological Review, 18(1), 122-136. https://doi.org/10/cnj9

Dunbar, N.E., Jensen, M.L., \& Burgoon, J. K., (2015). Effects of veracity, modality, and sanctioning on credibility assessment during mediated and unmediated interviews. Communication Research, 42(5), 649-674.

EU - European Union (2014), Directive 2014/95/EU of the European Parliament and the Council of 22 October 2014 amending Directive 2013/34/EU as regards disclosure of non-financial and diversity information by certain large undertakings and groups, Strasbourg. Available at: http://eur-lex.europa.eu/legal-content/EN/TXT/?uri=CELEX:32014L0095

Fifka, M. S. (2013). Corporate Responsibility Reporting and its Determinants in Comparative Perspective-a Review of the Empirical Literature and a Meta-analysis. Business Strategy and the Environment, 22(1), 1-35.

Fleming, M. (1997). Emancipation and illusion: Rationality and gender in Habermas's theory of modernity. University Park, PA: Pennsylvania State University Press.

Fombrun, C.J., \& Gardberg, N. (2000). Who's tops in corporate reputation? Corporate reputation review, $3(1), 13-17$. 
Fonseca, A. (2010). How Credible Are Mining Corporations' Sustainability Reports? A Critical Analysis of External Assurance under the Requirements of the International Council on Mining and Metals. Corporate Social Responsibility and Environmental Management, 17(6), 355-370.

Frias-Aceituno, J. V., Rodriguez-Ariza, L., \& Garcia-Sanchez, I. M. (2013). Is integrated reporting determined by a country's legal system? An exploratory study. Journal of Cleaner Production, $44,45-55$.

Friedman, A. L., \& Miles, S. (2001). Socially responsible investment and corporate social and environmental reporting in the UK: an exploratory study. British Accounting Review, 33(4), 523548.

Garegnani, G. M., Merlotti, E.P., Russo, A. A. (2015). Scoring Firms' Codes of Ethics: An Explorative Study of Quality Drivers. Journal of Business Ethics, 126, 541-557.

Global Reporting Initiative (GRI) and United Nation (UN) Global Compact (2018) Business Reporting on the SDGs. https://www.globalreporting.org/resourcelibrary/GRI UNGC Reporting-onSDGs_Practical_Guide.pdf

Gold Standard and the Worldwide Fund for Nature (WWF) Switzerland (2018) Business and the Sustainable Development Goals: Best practices to seize opportunity and maximise credibility. https://www.goldstandard.org/sites/default/files/documents/sdg report optimized.pdf

Gray, R. (2010). Is accounting for sustainability actually accounting for sustainability and how would we know? An exploration of narratives of organisations and the planet. Accounting, Organizations and Society, 35, 47-62.

Gray, R., Kouhy, R., \& Lavers, S. (1995). Corporate social and environmental reporting: a review of the literature and a longitudinal study of UK disclosure. Accounting, Auditing \& Accountability Journal, 8(2), 47-77. https://doi.org/10/cgv38p

Guthrie, J., \& Parker, L. D. (1989). Corporate Social Reporting: A Rebuttal of Legitimacy Theory. Accounting and Business Research, 19(76), 343-352. https://doi.org/10/gfv3gd

Habermas, J. (1984). The theory of communicative action. Boston: Beacon Press.

Habermas, J. (1985). The theory of communicative action, Volume 2: Lifeworld and system: A critique of functionalist reason. Boston, Massachusetts, Beacon Press publication.

Habermas, J. (1987). The Philosophical Discourse of Modernity. Translated by Frederick Lawrence. Cambridge: MIT Press, 1987.

Hackston, D., \& Milne, M.J. (1996). Some Determinants of Social and Environmental Disclosures in New Zealand, Accounting. Auditing \& Accountability Journal, 9(1), 77-108.

Hahn, R., \& Kühnen, M. (2013). Determinants of sustainability reporting: a review of results, trends, theory, and opportunities in an expanding field of research. Journal of Cleaner Production, 59, 521.

Hammond, K., \& Miles, S. (2004). Assessing quality assessment of corporate social reporting: UK perspectives. Accounting Forum, 28(1), 61-79. 
Hasseldine, J., Salama, A. I., \& Toms, J. S. (2005). Quantity versus quality: the impact of environmental disclosures on the reputations of UK Plcs. The British Accounting Review, 37(2), 231-248.

Helfaya, A., \& Kotb, A. (2016). Environmental Reporting Quality: An Analysis of Global Credibility Initiatives. In Handbook of Research on Green Economic Development: Initiatives and Strategies: IGI Global Book. 10.4018/978-1-5225-0440-5.ch027.

Helfaya, A., \& Whittington, M. (2019). Does designing environmental sustainability disclosure quality measures make a difference? Business Strategy and the Environment, 28(4), 525-541. https://doi.org/10.1002/bse.2262

Helfaya, A., Whittington, M., \& Alawattage, C. (2018). Exploring the quality of corporate environmental reporting: Surveying preparers' and users' perceptions. Accounting, Auditing \& Accountability Journal, 32(1), 163-193. https://doi.org/10.1108/AAAJ-04-2015-2023

Hodge, K., Subramaniam, N., \& Stewart, J. (2009). Assurance of sustainability reports: Impact on report users' confidence and perceptions of information credibility. Australian accounting review, 19(3), $178-194$.

Hopwood, A.G. (2009). Accounting and the environment. Accounting, Organizations and Society, $34,433-439$.

Hughes, P.J. \& Sankar M.R. (1997). The Impact of Litigation Risk on Discretionary Disclosure', Working Paper (University of California, Los Angeles).

Hur, W., Moon, T., \& Kim, H. (2020). When and How Does Customer Engagement in CSR Initiatives Lead to Greater CSR Participation? The Role of CSR Credibility and Customer-Company Identification. Corporate Social Responsibility and Environmental Management, (early view).

Husillos, J., Larrinaga, C., \& Álvarez, M. J. (2011). The emergence of triple bottom line reporting in Spain. Revista Española de Financiación y Contabilidad, 60(150), 195-219.

Intergovernmental Panel on Climate Change (IPCC). (2019). Special Report on Climate Change and Land. Retrieved from https://www.ipcc.ch/site/assets/uploads/2019/08/Fullreport-1.pdf (28/10/2019).

Ioannou, I., \& Serafeim, G. (2014). The consequence of mandatory corporate sustainability reporting: Evidence from four countries. In Harvard Business School Research Working Paper; Harvard Business School: Boston, MA, pp. 11-100.

Jackob, N. (2008). Credibility effects. In International Encyclopedia of Communication. Chichester, United Kingdom: Wiley

Jenkins, H., \& Yakovleva, N. (2006). Corporate social responsibility in the mining industry: Exploring trends in social and environmental disclosure. Journal of Cleaner Production, 14(3), 271-284.

Jensen, J.C., \& Berg, N. (2012). Determinants of traditional sustainability reporting versus integrated reporting. An institutionalist approach. Business Strategy and the Environment 21: 299-316.

Jones, M. J., \& Shoemaker, P. A. (1994). Accounting narratives: A review of empirical studies of content and readability. Journal of Accounting Literature, 13, 142-194. 
Kolk, A., (2004). A decade of sustainability reporting: Developments and significance. International Journal of Environment \& Sustainable Development, 3(1), 51-64.

Krippendorff, K. (2013). Content analysis: An introduction to its methodology. Thousand Oaks, CA: Sage.

La Porta, R., Lopez-de-Silanes, F., \& Shleifer, A. (2002). Government Ownership of Banks. The Journal of Finance, 57(1), 265-301.

Larsson, L. O., \& Ljungdahl, F. (2001). Seeking sustainability. Accountancy, 128(1295), 155-155.

Lindblom, C. K. (2010). The implications of organizational legitimacy for corporate social performance and disclosure. In R. Gray, J. Bebbington, \& S. Gray (Eds.), Social and environmental accounting (Vol. SAGE library in accounting and finances). Los Angeles: SAGE.

Lock, I., \& Seele, P. (2016). The credibility of CSR (corporate social responsibility) reports in Europe. Evidence from a quantitative content analysis in 11 countries. Journal of Cleaner Production, 122, 186-200. https://doi.org/10/f8kj4k

Lock, I., \& Seele, P. (2017). Measuring Credibility Perceptions in CSR Communication: A Scale Development to Test Readers' Perceived Credibility of CSR Reports. Management Communication Quarterly, 31(4), 584-613. https://doi.org/10/gb3b5k

Lucisano, P. \& Piemontese, M.E. (1988) GULPEASE: una formula per la predizione della difficoltà dei testi in lingua italiana, Scuola e città, XXXIX, 3, 110-24.

MacLean, R., \& Rebernak, K. (2007). Closing the credibility gap: The challenges of corporate responsibility reporting. Environmental Quality Management, 16(4), 1-6.

Martínez-Ferrero, J., \& García-Sánchez, I.-M. (2017). Coercive, normative and mimetic isomorphism as determinants of the voluntary assurance of sustainability reports. International Business Review, 26(1), 102-118. https://doi.org/10.1016/j.ibusrev.2016.05.009

Michelon G. (2011). Sustainability disclosure and reputation: A comparative study. Corporate Reputation Review, 14(2), 79-96.

Michelon, G., Pilonato, S., \& Ricceri, F. (2015). CSR reporting practices and the quality of disclosure: An empirical analysis. Critical Perspectives on Accounting, 33, 59-78.

Miller, G.S., \& Skinner D.K. (2015). The evolving disclosure landscape: How changes in technology, the media, and capital markets are affecting disclosure. Journal of Accounting Research, 53(2), 221-239.

Miras-Rodríguez, M., Bravo-Urquiza, F., \& Escobar-Pérez, B. (2020) Does Corporate Social Responsibility Reporting Actually Destroy Firm Reputation?. Corporate Social Responsibility and Environmental Management, (early view).

O'Donovan, G. (2002). Environmental disclosures in the annual report: Extending the applicability and predictive power of legitimacy theory. Accounting Auditing \& Accountability Journal, 15(3), 344-371. 
Odriozola, M. D., \& Baraibar-Diez, E. (2017). Is corporate reputation associated with quality of CSR reporting? Evidence from Spain. Corporate Social Responsibility and Environmental Management, 24(2), 121-132.

Perrini, F. (2006). SMEs and CSR theory: Evidence and implications from an Italian perspective. Journal of business ethics, 67(3), 305-316.

Pistoni, A., Songini, L., \& Bavagnoli, F. (2018). Integrated reporting quality: An empirical analysis. Corporate Social Responsibility and Environmental Management, 25, 489-507.

Raufflet, E., Barin Cruz, L., \& Bres, L. (2014). An assessment of corporate social responsibility practices in the mining and oil and gas industries. Journal of Cleaner Production, 84, 256-270.

Riffe, D., Lacy, S., \& Fico, F. (1998). Analyzing media messages. Using quantitative content analysis in research, London: Mahwah.

Roberts, P.W., \& Dowling, G.R. (2002). Corporate reputation and sustained superior financial performance. Strategic Management Journal, 23(12), 1077-1093.

Seele, P., \& Gatti, L. (2017). Greenwashing revisited: In search of a typology and accusation-based definition incorporating legitimacy strategies. Business Strategy and the Environment, 26(2), 239-252.

Seele, P., \& Lock, I. (2015). Instrumental and/or Deliberative? A typology of CSR communication tools. Journal of Business Ethics, 131(2), 401-414. https://doi.org/10/gftwnc

Sethi, S. P. (1975). Dimensions of corporate social performance: An analytical framework. California Management Review, 17(3), 58-64. https://doi.org/10/gfv3gb

Shenkar, O., \& Yuchtman-Yaar, E. (1997). Reputation, image, prestige, and goodwill: An interdisciplinary approach to organizational standing. Human Relations, 50(11), 1361-1381.

Simnett, R., Vanstraelen, A., \& Chua, W. F. (2009). Assurance on sustainability reports: an international comparison. The Accounting Review, 84(3), 937-967.

Suchman, M. C. (1995). Managing legitimacy: Strategic and institutional approaches. Academy of Management Review, 20(3), 571-610. https://doi.org/10.5465/AMR.1995.9508080331

Talbot, D., \& Barbat, G. (2019) Water Disclosure in the Mining Sector: An Assessment of the Credibility of Sustainability Reports. Corporate Social Responsibility and Environmental Management, (early view).

Unerman, J. (2000). Methodological issues: Reflections on qualification in corporate social reporting content analysis. Accounting, Auditing and Accountability Journal, 13(5), 667-680.

Unerman, J., \& Bennett, M. (2004). Increased stakeholder dialogue and the internet: towards greater corporate accountability or reinforcing capitalist hegemony? Accounting, Organizations and Society, 29(7), 685-707.

Venturelli, A., Caputo, F., Leopizzi, R., \& Pizzi, S. (2019). The state of art of corporate social disclosure before the introduction of non-financial reporting directive: A cross country analysis. Social Responsibility Journal, 15(4), 409-423.

Verrecchia, R. E. (2001). Essays on disclosure. Journal of accounting and economics, 32(1-3), 97-180. 
Zadek, S., \& Raynard, P. (2002). Stakeholder engagement: measuring and communicating quality. Accountability Quarterly, 19(2), 8-17.

Zinkin, M. (1998). Habermas on intelligibility. The Southern Journal of Philosophy, 36(3), 453-472. https://doi.org/10/dwh8b3

\section{Tables}

Table 1. - Credibility: dimensions and variables.

\begin{tabular}{|c|c|c|}
\hline \multirow{5}{*}{$\begin{array}{l}\mathrm{C} \\
\mathrm{R} \\
\mathrm{E} \\
\mathrm{D} \\
\mathrm{I} \\
\mathrm{B} \\
\mathrm{I} \\
\mathrm{L} \\
\mathrm{I} \\
\mathrm{T} \\
\mathrm{Y}\end{array}$} & Dimensions & Variables \\
\hline & $\begin{array}{c}\text { Under- } \\
\text { standability }\end{array}$ & $\begin{array}{l}\text { - Easy availability and consultation (online consultation; pdf document; pdf document + } \\
\text { interactive consultation) } \\
\text { - Readability (methodological note; index of readability) } \\
\text { - Explanation of key performance indicators (yes/no) }\end{array}$ \\
\hline & Reliability & $\begin{array}{l}\text { - Reference to reporting standards (GRI-G4 o GRI Standards) and level of application } \\
\text { - Environmental certifications (e.g., CDP - Carbon Disclosure Project; ISO 14001) (yes/no) } \\
\text { - Correspondence between auditing company of SER and auditing company that certifies the } \\
\text { financial statements (yes/no) } \\
\text { - Author of the report (internal/external) } \\
\text { - CSR manager (yes/no) } \\
\text { - Temporal comparison of key performance indicators (yes/no) } \\
\text { - Definition of improvement actions (yes/no) }\end{array}$ \\
\hline & Suitability & $\begin{array}{l}\text { - Stakeholder map (yes/no) } \\
\text { - Stakeholder engagement (yes/no) and level of engagement } \\
\text { - Materiality principle: application (yes/no); level of application } \\
\text { - Materiality matrix (yes/no) } \\
\text { - Correspondence between boundary of SE report and boundary report of financial report } \\
\text { (yes/no) }\end{array}$ \\
\hline & Exhaustivity & $\begin{array}{l}\text { - Environment in materiality matrix (yes/no) } \\
\text { - \% of environmental topics covered compared to those indicated by the GRI } \\
\text { - \% of environmental KPIs covered compared to those indicated by the GRI } \\
\text { - Number of words devoted to environmental theme/total number of words in the report }\end{array}$ \\
\hline
\end{tabular}


Table 2. - Sample: industry.

\begin{tabular}{l|c|c} 
Industry & No & Percentage \\
\hline Construction & 5 & $3 \%$ \\
Manufacturing & 58 & $38 \%$ \\
Transportation, Communications, Electric, Gas, and Sanitary Services & 23 & $15 \%$ \\
Wholesale Trade & 9 & $6 \%$ \\
Retail Trade & 7 & $5 \%$ \\
Real Estate & 37 & $24 \%$ \\
Services & 13 & $9 \%$ \\
\hline ESI* & 22 & $14 \%$ \\
\hline Total & 152 & $100 \%$ \\
\hline
\end{tabular}

* ESI are the following specific sub-sectors of the US SIC classification: 10 (mining), 13 (oil exploration), 26 (paper), 28 (chemical and allied products) 29 (petroleum refining), 33 (metals), 49 (utilities).

Table 3. - Sample: UN SDGs account.

\begin{tabular}{l|c|c} 
Environmental UN SDGs & No. of companies that mention it & Percentage \\
\hline SDG 6 & 32 & $21 \%$ \\
SDG 7 & 38 & $25 \%$ \\
SDG 12 & 41 & $27 \%$ \\
SDG 13 & 41 & $27 \%$ \\
SDG 14 & 7 & $5 \%$ \\
SDG 15 & 22 & $14 \%$ \\
\hline At least one Environmental SDGs & 56 & $37 \%$ \\
\hline
\end{tabular}

Table 4. - Credibility dimensions and variables: mean values.

\begin{tabular}{|c|c|c|c|}
\hline \multirow{9}{*}{$\begin{array}{l}\mathrm{C} \\
\mathrm{R} \\
\mathrm{E} \\
\mathrm{D} \\
\mathrm{I} \\
\mathrm{B} \\
\mathrm{I} \\
\mathrm{L} \\
\mathrm{I} \\
\mathrm{T} \\
\mathrm{Y}\end{array}$} & Dimensions & Variables & $\begin{array}{l}\text { Mean value } \\
\quad(0-10)\end{array}$ \\
\hline & \multirow{4}{*}{ Understandability } & Easy availability and consultation & 6.8 \\
\hline & & Methodological note & 9.7 \\
\hline & & Index of legibility - Gulpease Index & 6.2 \\
\hline & & Explanation of key performance indicators & 8.9 \\
\hline & \multirow{4}{*}{ Reliability } & $\begin{array}{c}\text { Level of application of reporting standards (GRI-G4 or GRI } \\
\text { Standards) }\end{array}$ & 5.6 \\
\hline & & Environmental certifications & 7.6 \\
\hline & & $\begin{array}{l}\text { Mismatch between auditing company of SER and auditing } \\
\text { company that certifies the financial statements }\end{array}$ & 0.9 \\
\hline & & Author of the report (internal) & 9.8 \\
\hline
\end{tabular}




\begin{tabular}{|c|c|c|}
\hline & CSR manager & 2.4 \\
\hline & Temporal comparison of key performance indicators & 9.0 \\
\hline & Definition of improvement actions & 3.9 \\
\hline \multirow{5}{*}{ Suitability } & Stakeholder map & 4.9 \\
\hline & Level of stakeholder engagement & 6.0 \\
\hline & Level of materiality principle application & 6.4 \\
\hline & Materiality matrix & 6.6 \\
\hline & $\begin{array}{c}\text { Correspondence between boundaries of SE report and financial } \\
\text { report }\end{array}$ & 6.7 \\
\hline \multirow{4}{*}{ Exhaustivity } & Environment in materiality matrix & 8.9 \\
\hline & $\%$ of topics covered compared to those indicated by the GRI & 5.8 \\
\hline & $\%$ of KPI covered compared to those indicated by the GRI & 3.3 \\
\hline & $\begin{array}{l}\text { Number of words devoted to environmental issues / total number of } \\
\text { words in the report }\end{array}$ & 2.6 \\
\hline
\end{tabular}

Table 5. - Credibility dimensions: descriptive statistics.

\begin{tabular}{l|c|c|c|c|c} 
Dimensions & Obs. & Mean & Std. dev. & Min (0) & Max (10) \\
\hline Understandability & 152 & 7.913092 & 1.032670 & 3.09 & 9.60 \\
Reliability & 152 & 5.613421 & 1.570079 & 1.90 & 9.52 \\
Suitability & 152 & 6.139474 & 2.653404 & 0.00 & 10.00 \\
Exhaustivity & 152 & 5.143684 & 1.564698 & 0.10 & 8.56 \\
\hline Credibility & 152 & 6.202039 & 1.157425 & 2.59 & 8.52 \\
\hline
\end{tabular}

Table 6. - Credibility dimensions: Spearman's Rho.

\begin{tabular}{l|l|l|l|l} 
& Understandability & Reliability & Suitability & Exhaustivity \\
\hline Understandability & 1.0000 & & & \\
Reliability & $0.3073^{* * *}$ & 1.0000 & & \\
Suitability & 0.1103 & $0.2256^{* * *}$ & 1.0000 & \\
Exhaustivity & $0.2202^{* * *}$ & $0.3123^{* * *}$ & $0.1520^{*}$ & 1.0000 \\
\hline
\end{tabular}

$* * * \mathrm{p}<0.01$

$* * \mathrm{p}<0.05$

$* \mathrm{p}<0.1$

Table 7. - Control and independent variables: descriptive statistics.

\begin{tabular}{|c|c|c|c|c|c|c|}
\hline $\begin{array}{l}\text { Control and } \\
\text { independent variables }\end{array}$ & Obs. & Mean & Std. dev. & Min & Max & Freq. \\
\hline
\end{tabular}




\begin{tabular}{l|c|c|c|c|c|c} 
ESI & 152 & 0.1447368 & 0.3529984 & 0 & 1 & $14 \%$ \\
SDG & 152 & 0.3684211 & 0.483971 & 0 & 1 & $37 \%$ \\
Scandal \& Pressure & 152 & 0.1118421 & 0.316214 & 0 & 1 & $11 \%$ \\
Experience & 152 & 0.4276316 & 0.4963706 & 0 & 1 & $43 \%$ \\
Stand-alone & 152 & 0.7434211 & 0.4381888 & 0 & 1 & $74 \%$ \\
Profitability & 152 & 0.0153947 & 0.103052 & -0.92 & 0.24 & - \\
Size & 152 & 13.48303 & 1.768851 & 5.97 & 18.2 & - \\
Assurance & 152 & 0.9802632 & 0.1395544 & 0 & 1 & $98 \%$ \\
Visibility & 152 & 0.1315789 & 0.3391499 & 0 & 1 & $13 \%$ \\
Leverage & 152 & 0.5167763 & 0.2454341 & 0.02 & 1.87 & - \\
\hline
\end{tabular}

Table 8. - Multiple Linear Regression (Credibility).

\begin{tabular}{|c|c|c|c|c|}
\hline & $\beta$ & Std. Err. & Obs. & $\operatorname{VIF}(I / N I F)$ \\
\hline Industry dummy & \multicolumn{4}{|c|}{ Yes } \\
\hline ESI & 0.004619 & 0.3195315 & 152 & $1.85(0.54)$ \\
\hline SDG & 0.2455103 & 0.2062674 & 152 & $1.45(0.69)$ \\
\hline Scandal \& Pressure & -0.0887671 & 0.3076499 & 152 & $1.37(0.73)$ \\
\hline Experience & $0.4679052^{* *}$ & 0.1984406 & 152 & $1.41(0.71)$ \\
\hline Stand-alone & $0.5621962 * * *$ & 0.2063418 & 152 & $1.19(0.84)$ \\
\hline Profitability & -0.814986 & 1.040155 & 152 & $1.67(0.60)$ \\
\hline Size & 0.0813836 & 0.0673634 & 152 & $2.06(0.48)$ \\
\hline Assurance & $1.587965^{* *}$ & 0.6358915 & 152 & $1.14(0.87)$ \\
\hline Visibility & -0.1147351 & 0.3099209 & 152 & $1.60(0.62)$ \\
\hline Leverage & -0.4935799 & 0.4197737 & 152 & $1.54(0.65)$ \\
\hline Intercept & 3.10175 & 1.159266 & 152 & - \\
\hline
\end{tabular}

$* * * \mathrm{p}<0.01$

$* * \mathrm{p}<0.05$

$* \mathrm{p}<0.1$

Table 9. - Comparison of means tests (Credibility $t$-test).

\begin{tabular}{l|l|l|l|l} 
& Sample mean & Rest of the sample mean & Difference & t-test \\
\hline Industry 5 & 7.03 & 6.06 & 0.97 & $-3.89 * * *$
\end{tabular}




\begin{tabular}{l|l|l|l|l} 
Industry 9 & 5.54 & 6.26 & -0.72 & $2.16^{* *}$ \\
ESI & 6.64 & 6.13 & 0.51 & $-1.934^{*}$ \\
\hline SDG & 6.64 & 5.95 & 0.69 & $-3.72^{* * *}$ \\
Experience & 6.61 & 5.90 & 0.71 & $-3.92^{* * *}$ \\
Stand-alone & 6.35 & 5.78 & 0.57 & $-2.68^{* * *}$ \\
\hline
\end{tabular}

Industry 5 = Transportation, Communications, Electric, Gas, and Sanitary Services

Industry $9=$ Services

$* * * \mathrm{p}<0.01$

$* * \mathrm{p}<0.05$

$* \mathrm{p}<0.1$

\section{Figure Legend}

Figure 1. - The role of Credibility in the track between SER and corporate legitimacy.

\section{Appendices}

Measurement criteria of credibility items:

UNDERSTANDABILITY

- EASY AVAILABILITY AND CONSULTATION:

- (1) if the report is available only through an online consultation;

$\circ$ (2) if the report is available through a pdf document;

- (3) if the report is available through a pdf document in addiction to an interactive online consultation.

- READABILITY:

○ Methodological note: (0) present; (1) absent.

- Index of readability: Gulpease Index, which is an index of the readability of a text calibrated on the Italian language. It has the advantage of using the length of words measuring the number of letters instead of syllables, which simplifies the automatic calculation. To apply this indicator, each report was converted from a pdf to a word file

- EXPLANATION OF KEY PERFORMANCE INDICATOR:

○ (0) absent or only partial;

$\circ$ (1) present.

\section{$\underline{\text { RELIABILITY }}$}

- REFERENCE TO REPORTING STANDARDS (GRI-G4 o GRI Standards) AND LEVEL OF APPLICATION:

○ (1) not declared, referenced, C;

○ (2) core, B;

- (3) comprehensive, A.

- ENVIRONMENTAL CERTIFICATIONS (e.g., CDP - Carbon Disclosure Project; ISO 14001):

○ (0) absent;

$\circ$ (1) present. 
- CORRESPONDENCE BETWEEN AUDITING COMPANY OF SER AND AUDITING

COMPANY THAT CERTIFIES THE FINANCIAL STATEMENTS:

○ (0) no, different companies;

O (1) yes, the same auditing company.

- $\quad$ AUTHOR OF THE REPORT:

○ (0) external;

○ (1) internal.

- CSR MANAGER (general CSR manager, environmental manager, social manager, health/safety manager):

○ (0) absent;

○ (1) present.

- TEMPORAL COMPARISON OF KEY PERFORMANCE INDICATORS:

○ (0) no temporal comparison;

- (1) presence of a temporal comparison but only when an improvement is evident;

$\circ$ (2) presence of a temporal comparison both in case of improvement and worsening.

- DEFINITION OF IMPROVEMENT ACTIONS:

$\circ$ (0) absent;

$\circ$ (1) present.

\section{SUITABILITY}

- STAKEHOLDER MAP:

○ (0) absent;

○ (1) present.

- STAKEHOLDER ENGAGEMENT AND LEVEL OF ENGAGEMENT:

○ (0) absent or not declared;

○ (1) indirect and partial involvement (low-spectrum initiatives, low numbers, few categories involved, remote initiatives, low direct involvement);

○ (2) direct and total involvement (broad spectrum initiatives, high numbers, different categories involved, initiatives also in presence, high direct involvement).

- MATERIALITY PRINCIPLE APPLICATION AND LEVEL OF APPLICATION:

$\circ \quad(0)$ absent or not declared;

○ (1) only cited;

- (2) in addition, declaration of how the material issues have been detected;

○ (3) in addition, the material arguments are clearly explained;

○ (4) in addition, the process and the results are very detailed;

○ (5) in addition, the report pays particular attention and space to material issues.

- MATERIALITY MATRIX:

○ (0) absent;

○ (1) present.

- CORRESPONDENCE BETWEEN BOUNDARY OF SE REPORT AND BOUNDARY REPORT OF FINANCIAL REPORT:

○ (0) not corresponds;

$\circ$ (1) corresponds.

\section{EXHAUSTIVITY}

- ENVIRONMENT IN MATERIALITY MATRIX:

○ (0) no environmental issues are present among those surveyed as materials;

$\circ$ (1) there are environmental issues among those identified as materials. 
- \% OF ENVIRONMENTAL TOPICS COVERED COMPARED TO THOSE INDICATED BY THE GRI: percentage value of the topics covered out of the total of those indicated by the GRI standards adopted in the report.

- \% OF ENVIRONMENTAL KPIS COVERED COMPARED TO THOSE INDICATED BY THE GRI: percentage value of the kpis covered out of the total of those indicated by the GRI standards adopted in the report.

- NUMBER OF WORDS DEVOTED TO ENVIRONMENTAL THEME/TOTAL NUMBER OF WORDS IN THE REPORT: value expressed as a percentage excluding index, methodology, chairman's letter, and anything not specifically related to CSR/Sustainability/Environmental issues. 